\title{
MANAGING PRICE RISK IN THE CORN MARKET USING OPTION STRATEGIES
}

\author{
Monika Harčariková ${ }^{1}$ \\ ${ }^{1}$ Department of Finance, Faculty of Economics, Technical University of Košice, Letná 9, 04001 Košice, \\ Slovak Republic
}

\begin{abstract}
HARČARIKOVÁ MONIKA. 2018. Managing Price Risk in the Corn Market Using Option Strategies. Acta Universitatis Agriculturae et Silviculturae Mendelianae Brunensis, 66(3): 767-779.

In today's economy, the agricultural sector faces a high degree of risk due to increasing commodity price volatility. Therefore, it is important to know how to manage the price risk effectively. The main contribution of the paper is to introduce and analyse the ways of the managing price risk in the corn market using option strategies. The purpose of the paper is to analyse three hedging option strategies, i.e. Strap, Long Strangle and Short Put Ladder strategy with the aim to prove how it is possible to hedge against falling prices. There is examined analytical expressions of vanilla options for the creation of selected hedging strategies in the corn market with the presentation of their pros and cons. General expressions of the corn selling price intervals are derived from various hedged scenarios of all variants. Based on derived theoretical hedging variants, the contribution of the approach is considered for the application to the corn market, where the corn options on futures contracts are traded on the Chicago Board of Trade. Also, the evaluation of the sellers' profitability is examined at the future trade date. Finally, a comparative analysis of the proposed hedging techniques with the various strike prices is displayed with the presentation of recommendations for potential corn sellers. The paper's aim is to extend the previous research based on different hedging tools and it may be widened in the scientific and the commercial area.
\end{abstract}

Keywords: risk management, options, option strategy, agricultural market, corn futures, volatility, falling prices

\section{INTRODUCTION}

Over the last two decades, commodity prices have been more volatile. This extreme price volatility makes it hard to run a business and to plan and invest for the future. Mainly agricultural sector is exposed to many more unpredictable risks and uncertainties, whether caused by government policy, foreign exchange rates, climatic disasters, or political/civil instability. Also, the corn price does not depend only on the local conditions, but mainly on the situation of the largest corn producers. Therefore, producers are uncertain whether they will receive a high price or a low price for their harvest at the time of sale. Due to this fact, they need protection against falling prices for crops.

The contribution of this paper is to explore how the use of financial engineering principles, i.e. options and option strategies, can manage the risks that face the agricultural commodity sellers, due to fluctuating and unpredictable prices of their production. The aim is to help the agricultural sellers in the commodity market by integrating options and option strategies into the effective hedging strategies. There can be individuals, firms which are responsible for the sale of the physical raw commodities (e.g. corn, soybean, wheat...) or farmers and exporters. Each seller has a different role in the agricultural sector, but almost every one of them shares a common risk (falling prices) and the common need for managing the commodity risk. The contribution of the paper is to introduce and analyse the creation of three option strategies, i.e. Strap, Long Strangle and Short Put Ladder strategy and their use on hedging against falling markets. We have proved the creation of selected options strategies suitable for hedging by using the analytical 
expressions of individual vanilla options. We have examined how these hedging techniques allow the sellers to establish a floor (minimum) selling price by providing different risk management benefits. Also, we have evaluated the profitability of the proposed hedging variants for particular intervals of the corn spot price at the future trade date followed by the comparative analysis of the given variants with the recommendation of the best alternatives for sellers. The approach is focused on the application for corn market based on real-traded American vanilla option on futures data gained from the Chicago Board of Trade, where the corn sellers are introduced as potential hedgers. Based on the research of studies introduced in the literature review, there is necessary to manage the agricultural commodity price risk. New ways of risk management are option strategies, therefore their analysis and application on the corn market introduce their main contribution to widen existing studies. However, our results can be applied to various commodities, for example metals or energy commodities.

\section{Literature review}

In recent years, commodity price risk management began to be studied and implemented for various purposes to protect institutions and individuals from bearing losses associated with the fluctuations in the prices of commodities (see e.g., Rata and Cinade, 2009; Stulz, 2002). In this case it is necessary to present the methods of risk management in the commodity market using literature review to continue our research.

Mainly hedging techniques are used to reduce the exposure to various risks. In financial markets, hedging becomes more complicated than simply paying an insurance company a fee every year. Hedging (the risk management) means strategically using instruments (known as derivatives) in the market to offset the risk of any adverse price movements as it is shown byZmeškal (2004). It means that producers hedge one investment by making another with the aim to reduce potential loss. Taleb (1997) defines financial derivatives as securities whose price is dependent upon or derived from one or more underlying assets. Main financial derivative instruments for commodity price risk management are options. However, options have the reputation of being risky because producers have to be correct in determining not only the direction of the crop's movement but also the magnitude and the timing of this movement. Hull (2012) defines a call (put) option as a financial security granting its holder the right (but not the obligation) to buy (or sell) a given underlying asset, at a predetermined price (referred as the strike or exercise price), at a given date (referred as the maturity date). In agricultural markets, commodity options are referred as options on futures contract. In the case of the agricultural market, the underlying asset is agricultural commodity futures contract. Only American-style of options is used, i.e. it may be exercised at any time prior to its expiration. Option premium represents the cost of buying an option. It is a non-refundable payment that the buyer of an option pays to the seller at the time of buying the option. The potential buyer of an option, whether a put or a call, has a choice to choose many different strike prices, each with a different value at a given day. It is valid, that a lot of option strategies can be created and suitably defined to bullish, bearish, or direction neutral outlooks with anticipating high volatility or low volatility in the markets as it is presented by Cohen (2005), Hull (2012) or Kolb (1995; 2010). Besides that, there are many other applications of derivatives, and also new types are being invented.

Today a lot of scientific papers deal with the management of the commodity risk with the emphasis on their contribution to the literature. For example, companies or farmers can hedge their weather risk to compensate their possible extra costs for an unexpectedly hot or cold season (see, e.g., Shannon and Motha, 2015; Sivakumar and Motha, 2007; Taušer and Čajka, 2014b). On the other hand, Bobriková (2016) showed how weather derivatives (based on option strategies) are used to hedge the financial risk of a suboptimal temperature condition in the Slovak town Košice. As documented by Larson et al. (1998), many developing countries have begun using commodity derivatives markets to hedge commodity price risks, because they found, that commodity price instability has a negative impact on economic growth, income distribution and poverty alleviation. Like stated Garcia and Leuthold (2004) and Geman (2005; 2008), agricultural commodity futures and options play an important role in the commodity price risk management with focusing on reducing the costs for farmers. Leoni et al. (2013) investigated the energy derivatives where was proved the existence of the locally risk-minimizing (LRM) hedging strategy with its illustration for stochastic volatility models. For example studies (Armeanu et al., 2013; Tomek and Peterson, 2001) evaluated the optimal hedging ratio and the level of knowledge about producer's marketing strategies to manage agricultural price risk.

Our paper's approach is based on options and option strategies on futures, which are the significant part of financial engineering. Many studies (see e.g., Amaitiek et al., 2010; Rusnáková et al., 2015) analysed option strategies in hedging against increasing price applied in the gold market. Also, there are some studies dealing with option strategies using for a drop in risk management. Šoltés and Harčariková (2015) analysed the risk management in oil market using New 1 hedging strategy created by barrier options. Short Put Ladder strategy was investigated by Šoltés and Amaitiek (2010). Rusnáková and Šoltés (2012) analysed Long Strangle strategy and Šoltés and Rusnáková, (2013) examined Inverse Vertical Ratio Put Spread strategy using barrier options, all for hedging against a price drop. Also, Rusnáková (2015) and Taušer and Čajka (2014a) 
introduced new hedging techniques (long put strategy) in agricultural risk management. Based on the related theoretical framework mentioned above, we examine the financial engineering principles to the creation of our selected option strategies which are suitable for hedging against falling prices. The analysis of Strap, Long Strangle and Short Put Ladder strategies based on analytical expression of profit function and their application in the corn market introduce their main contribution to widen the existing studies.

\section{MATERIALS AND METHODS}

For moderately sophisticated investors, new tools as options are attractive protections due to their leveraged nature, the ability to limit their expenditure and their general versatility. Therefore, these instruments are recently used mainly in the risk management, where are intended to move in a different direction than the remainder of the underlying asset. A number of tools are available to manage risks in agriculture, but in the paper, we deal only with options on futures contracts and different option strategies used in the price risk management, which are available to producers.

According to Hull (2012) futures contracts are standardized according to the quality, quantity, and delivery time of a given commodity in the future. Hedging with the futures is based on the opposite positions in the cash and futures market prices. It is valid if the value of the hedger's position in the cash market increases, the value of the hedger's position in the futures market decreases and vice versa. It means that taking opposite positions allows losses in one market to be offset by gains in the other. This movement between the commodity cash price and futures price is not necessarily identical and the given difference is known as the basis, i.e. cash price - futures price $=$ basis at a specific point in time. Given basis affects the value of the contracts used in hedging. If the underlying asset is hedged and the futures contracts on the underlying asset are the same, the basis should be zero at the expiration of the futures contract.

For the better idea of how hedging works, let's suppose it is June and you are a corn farmer with a crop in the field. Let's assume that the current cash market price for corn to be delivered in December is 3.50 USD per bushel. To protect yourself you can hedge by selling a corresponding number of bushels in the futures market now (current future market price for corn to be delivered in December is 3.80 USD per bushel) and buying them back later when it is time to sell your crops in the cash market. This operation is marked as a short futures market position. In this case, the approximate price you can establish by hedging is 3.50 USD per bushel (i.e. 3.80 USD-0.30 USD), provided basis is 30 under. Simultaneously you expect the price drop in December where the corn cash price declines by 0.45 USD per bushel and the corn futures price declines by 0.40 USD per bushel. Now the basis is 0.35 USD under (3.05 USD-3.40 USD) and you buy December Corn futures for the price 3.40 USD per bushel. The gain from the hedged operation in the future market is $\$ 0.40$ per bushel. At the same time, you sell corn in the cash market for 3.05 USD per bushel. The basis change is 0.05 USD under. Due to this fact your net selling price is 3.45 USD per bushel (i.e. 3.05 USD + 0.40 USD), where this price is lower than the cash market price 3.50 USD per bushel. The following Tab. I. represents the results of the negative basis from the change between cash and futures market price.

Using options there is possible to protect the commodity price change, where the commodity sellers establish the floor (minimum) selling prices for protection against the falling markets. Our research is focused on options and option strategies on futures, therefore the methodology is based on these tools. The methodology of the paper introduces an analytical expressions of the profit functions for options and option strategies in the corn market. The first time basic option positions in an analytical expression were presented to the readers by Šoltés (2002), where all relations of vanilla options are derived. Based on the review of existing literature mentioned above, we analyse selected option strategies (specifically Strap, Long Strangle and Short Put Ladder) in the corn markets, where the whole analysis concentrates on corn sellers, who want to hedge against a price drop. Specifically, options on futures are analysed due to the fact, that there are more liquid and easier to trade than the underlying asset. Also, futures options are normally settled in cash. In this case, theoretical hedged models are developed for sellers who are exposed to several types of risks.

Now, sellers suppose that they will sell $n$ pieces of the corn at the future trade date $T$, but they are

I: Basis change and the short hedger

\begin{tabular}{lccccc}
\hline & $\begin{array}{c}\text { Corn cash } \\
\text { market position }\end{array}$ & $\begin{array}{c}\text { Corn cash price } \\
\text { (USD) }\end{array}$ & Corn futures market position & $\begin{array}{c}\text { Corn futures } \\
\text { price (\$) }\end{array}$ & Basis (\$) \\
\hline June & - & $3.50 \mathrm{USD} / \mathrm{bu}$ & Sell December Corn futures & $3.80 \mathrm{USD} / \mathrm{bu}$ & -0.30 \\
November & Sell Corn & $3.05 \mathrm{USD} / \mathrm{bu}$ & Buy December Corn futures & $3.40 \mathrm{USD} / \mathrm{bu}$ & -0.35 \\
Change & -0.45 & & 0.40 & -0.05 \\
Selling price & & $\begin{array}{l}3.05+0.40=3.45 \mathrm{USD} / \mathrm{bu} \\
\text { or } 3.50-0.05=3.45 \mathrm{USD} / \mathrm{bu}\end{array}$ \\
\hline
\end{tabular}


afraid of its price drop in the market. The producer's income from the sale of the unsecured position at the future trade date $T$ is:

$I\left(S_{T}\right)=n \cdot S_{T}$,

where $S_{T}$ is the corn spot price at the future trade date $T$.

A put option provides insurance for hedging against the drop in commodity prices. Mainly there are used option positions as buying or selling put options and buying call options in option strategies, where $X$ is the strike price, $p$ is the put option premium and $c$ is the call option premium. For easier understanding of given options, the following relations are derived in analytical expressions. The profit function from buying $n$ of put options is

$$
P\left(S_{T}\right)= \begin{cases}-n \cdot\left(S_{T}-X+p_{B}\right) & \text { if } S_{T}<X \\ -n \cdot p_{B} & \text { if } S_{T} \geq X\end{cases}
$$

meanwhile for selling $n$ of put options is

$$
P\left(S_{T}\right)= \begin{cases}n \cdot\left(S_{T}-X+p_{S}\right) & \text { if } S_{T}<X, \\ n \cdot p_{S} & \text { if } S_{T} \geq X\end{cases}
$$

and for buying $n$ of call options is

$$
P\left(S_{T}\right)= \begin{cases}-n \cdot c_{B} & \text { if } S_{T}<X \\ n \cdot\left(S_{T}-X-c_{B}\right) & \text { if } S_{T} \geq X\end{cases}
$$

However, hedging can be achieved by choosing proper strike prices of given options, as well as the costs of this insurance. Based on the obtained theoretical results of our approach, the analysis is applied to the corn market, specifically corn options on futures. The corn that is traded on the Chicago Board of Trade (CBOT) is animal feed, not the sweet corn bought in the supermarket. The next part introduces used data in the practical part of the approach.

\section{Data}

The corn seller is a potential hedger which wants to hedge against possible falling corn price in the future using selected option strategies. In this case, each corn seller chooses the strategy according to his needs and willingness to take a risk. The proposed analysed and compared hedging techniques assume the corn futures options prices quotes for December 2018 corn contract traded on the Chicago Board of Trade (CBOT). Basic key hedging information is presented in Tab. II.

The option premiums for call and put options in December (the settlement date 14th December 2018) corn futures are in Tab. III. All data consist of the American-exercise corn futures options, which are publicly available prices and obtained from the CME Group (CME website, cmegroup.com) and the Chicago Board Options Exchange (CBOE) with the possibility of buying or selling. They are traded by the futures contract and one standard corn option contract size is 5000 bushels.

The dataset for our analysis consists of 10 vanilla call/put options, where the strike prices of the real vanilla call options are in the range of 3.5-4.4. The used currency of an underlying asset and option premiums is in USD/per bushel. Our selected strike prices for analysed strategies have to fulfill the condition of $\mathrm{X}_{1}<\mathrm{X}_{2}<\mathrm{X}_{3}$. Based on the dataset, all possible hedging techniques are proposed and analysed in the total amount of 170 variants, i.e. for Strap strategy 10 variants,

II: Keyhedging information.

\begin{tabular}{ccccc}
\hline Underlying asset & Issue date & Issue price & Maturity date & Multiplier \\
\hline Corn futures & 29th August 2017 & 3.97 USD/per bushel & 14th December 2018 & $1: 1$ \\
\hline
\end{tabular}

Source: CME Group (2017)

III: Call/put option prices on corn futures with settlement in December 2018

\begin{tabular}{ccc}
\hline Call options & Strike Price & Put options \\
\hline 0.550 & 3.5 & 0.085 \\
0.481 & 3.6 & 0.115 \\
0.423 & 3.7 & 0.156 \\
0.373 & 3.8 & 0.205 \\
0.326 & 3.9 & 0.257 \\
0.282 & 4.0 & 0.312 \\
0.243 & 4.1 & 0.372 \\
0.213 & 4.2 & 0.440 \\
\hline 0.165 & 4.3 & 0.513 \\
\hline
\end{tabular}

Source: CME Group (2017)

Note: USD/per bushel 
for Long Strangle 45 variants and for Short Put Ladder strategy 120 variants. However only selected variants are presented in the paper. Also, to show results in easier way, the comparison of analysed strategies present variants for Strap $\left(\mathrm{X}_{1}=3.6\right)$, Long Strangle $\left(\mathrm{X}_{1}=3.6\right.$ and $\left.\mathrm{X}_{2}=4.0\right)$ and Short Put Ladder $\left(X_{1}=3.6 ; X_{2}=3.8\right.$ and $\left.X_{3}=4.2\right)$.

It is valid, commodity options are called standard options that have the same contract month name as the underlying futures contract. Exercising a standard option will result in a futures position in the same contract month as the option at the specified strike price. For better understanding, the calculations illustrated in the below examples did not take into account transaction or any others charges and a basis is 0 USD. Also, the prices per bushel are considered. The calculated results of all analysed variants are not reported in the paper but are available upon request. Using hedging option strategies, the seller would like to gain from the future market transactions in order to cover the loss from the future falling cash market corn price. Next part introduces three selected hedging option strategies, which are applied in the corn market.

\section{RESULTS}

Agricultural sellers are exposed to commodity risk connected with the uncertainty about the expected value of the price drop from the sale of an agricultural commodity.

Now assume the corn seller expects the corn price is going to drop in future. Therefore, he decides to hedge against a possible falling corn price using the futures options. By means of options and different combined option strategies, new attractive relations and investment opportunities are created. In the end, each commodity seller will have to make a decision which option strategy is the best according to his risk-profit profile.

Tab. IV. shows selected option strategies suitable for risk management against a commodity price drop. These strategies help to manage the falling corn price risks with the establishment of the minimum selling price. For sellers, it is important to select a suitable option hedging strategy based on the volatility of the underlying asset, the attitude to risk and expectation of the reward. In this view for each strategy, there are some strengths and weaknesses, which will be introduced in the following part.

With any trade, the traders that are looking to make some decisions, must be aware of their potential risk and reward. On the other side, the strategies with uncapped risk are not necessarily all bad, but traders should be at least aware of what they are getting into.

Next parts introduce the hedging variants designed for the drop, where is needed the understanding of the option strategies creation for their use in agricultural risk management.

\section{Strap strategy}

The first analysed strategy is Strap (referred as S). This strategy belongs to the high volatility strategies with the underlying asset's price moving explosively in either direction, preferably more bullish slant. This strategy can be used for risk management in a down market. The strategy is created by buying more call options than put options, i.e. as by buying $n$ put options with a strike price $X_{1}$, the premium $p_{1 в}$ per option and simultaneously by buying $2 n$ call options with the same strike price $X_{1}$ the premium $c_{2 B}$ per option. Therefore, the strategy is more expensive than others below introduced. Using this strategy two variants of the commodity price scenarios can occur in the future. If the underlying asset's price remains around the strike price, we make our maximum loss in the amount of paid put and call option premiums. If it moves explosively in either direction, we make higher profits in comparison to the unhedged position, particularly if the underlying moves up. Although this strategy appears as easier, its use is recommended only for expert hedgers according to Cohen (2005).

The future market reward and final hedged selling price in case of used Strap strategy is given in Tab. V. The corn producer can hedge the floor price

IV: Principal forms of option strategies and their using

\begin{tabular}{lcccccc}
\hline & $\begin{array}{c}\text { Proficiency of } \\
\text { Traders }\end{array}$ & Direction & Volatility & Risk profile & $\begin{array}{c}\text { Reward } \\
\text { potential }\end{array}$ & Strategy type \\
\hline Strap & expert & bullish & high & capped & uncapped & capital gain \\
Long Strangle & intermediate & neutral & high & capped & uncapped & capital gain \\
Short Put Ladder & advanced & bearish & high & capped & uncapped & income \\
\hline
\end{tabular}

Source: Own design according to Cohen (2005)

V: Strap strategy and its final selling price

\begin{tabular}{cccc}
$\begin{array}{c}\text { Price scenarios of selected } \\
\text { commodity }\end{array}$ & Cash market price & Future market reward & Final hedged selling price \\
\hline $\mathrm{ST}<\mathrm{X}_{1}$ & $\mathrm{~S}_{\mathrm{T}}$ & $\mathrm{X}_{1}-\mathrm{S}_{\mathrm{T}}-\mathrm{p}_{1 \mathrm{~B}}-2 \mathrm{c}_{2 \mathrm{~B}}$ & $\mathrm{X}_{1}-\mathrm{p}_{1 \mathrm{~B}}-2 \mathrm{c}_{2 \mathrm{~B}}$ \\
$\mathrm{ST} \geq \mathrm{X}_{1}$ & $\mathrm{~S}_{\mathrm{T}}$ & $2 \mathrm{~S}_{\mathrm{T}}-2 \mathrm{X}_{1}-\mathrm{p}_{1 \mathrm{~B}}-2 \mathrm{c}_{2 \mathrm{~B}}$ & $3 \mathrm{~S}_{\mathrm{T}}-2 \mathrm{X}_{1}-\mathrm{p}_{1 \mathrm{~B}}-2 \mathrm{c}_{2 \mathrm{~B}}$ \\
\hline
\end{tabular}

Source: Own design 
position in the amount of $X_{1}-p_{1 B}-2 c_{2 B}$, represents the sum of analytical form of the relation (1), (2) and (4).

Assume the corn seller buys a December Corn futures put option contract at a strike price 3.6 USD/per bushel with the option premium 0.115 USD/per bushel and simultaneously buys 2 December Corn futures call option contracts at the same strike price 3.6 USD/per bushel with the option premium $0.481 \mathrm{USD} /$ per bushel. If we assume different strike price, for example, 4.2 USD/per bushel, then the same process is applied. Calculated profit or loss is the difference between the final corn selling price (as a hedged position) and the cash market price (as an unhedged position) at future time $T$. In this case, Tab. VI. presents the final corn selling prices for various strike prices with different future price scenarios and the profit or loss from this hedging.

The paid put and call option premiums decrease the final selling corn prices. The minimum selling price is 2.523 USD per bushel (for strike price 3.6) and 3.334 USD per bushel (for strike price 4.2). The minimum selling price presents the strike price reduced by premiums paid for the options. The price sensitivity of the given strategy is based on changes in the strike prices. The higher strike price is, the lower call (higher put) option premium is and vice versa. If the strike price is higher, lower costs are needed for buying of given options and therefore the higher floor selling price is ensured. Comparison of the created hedging variants with the unhedged position based on the results noted into the Tab. VI. is graphically illustrated in Fig. 1.

This strategy is more expensive in comparison to others, because the creation of given hedging strategy is only based on buying options. However, the strategy is still interesting if there is significant movement of the underlying asset and option prices which can secure a higher profit.

\section{Long Strangle strategy}

The Long Strangle strategy (referred as LS) is the easiest volatility strategy from our analysed strategies. The LS strategy is created similar to previous one, but there are small changes of the parameters. The creation consists of the buying $n$ put options with a strike price $X_{1}$, the premium $p_{1 \text { B }}$ per option and buying $n$ call options with a higher strike price $X_{2}$, the premium $c_{2 B}$ per option with the same expiration date. This strategy can be created also the second way as buying call options with lower strike price $X_{1}$ and at the same time buying put options with higher strike price $X_{2}$. In our applications, we do not contemplate with this second hedging way. Using of LS strategy is not only

VI: Strap strategy and its final selling price

\begin{tabular}{|c|c|c|c|c|c|}
\hline \multirow{2}{*}{ Strike price } & \multirow{2}{*}{$\begin{array}{l}\text { Corn price } \\
\text { scenarios }\end{array}$} & \multirow{2}{*}{ Cash market price } & \multirow{2}{*}{$\begin{array}{l}\text { Final hedged } \\
\text { selling price }\end{array}$} & \multicolumn{2}{|c|}{ Profit / Loss of the hedging } \\
\hline & & & & Min & Max \\
\hline 3.6 & $\begin{array}{c}\mathrm{S}_{\mathrm{T}}<2.523 \\
2.523 \leq \mathrm{S}_{\mathrm{T}}<3.6 \\
3.6 \leq \mathrm{S}_{\mathrm{T}}<4.139 \\
\mathrm{~S}_{\mathrm{T}} \geq 4.139\end{array}$ & $\mathrm{~S}_{\mathrm{T}}$ & $\begin{array}{c}2.523 \\
2.523 \\
3 \mathrm{~S}_{\mathrm{T}}-8.277 \\
3 \mathrm{~S}_{\mathrm{T}}-8.277\end{array}$ & $\begin{array}{c}0 \\
0 \\
0 \\
-1.077\end{array}$ & $\begin{array}{c}2.523 \\
-1.077 \\
-1.077 \\
+\infty\end{array}$ \\
\hline
\end{tabular}

Source: Own calculations

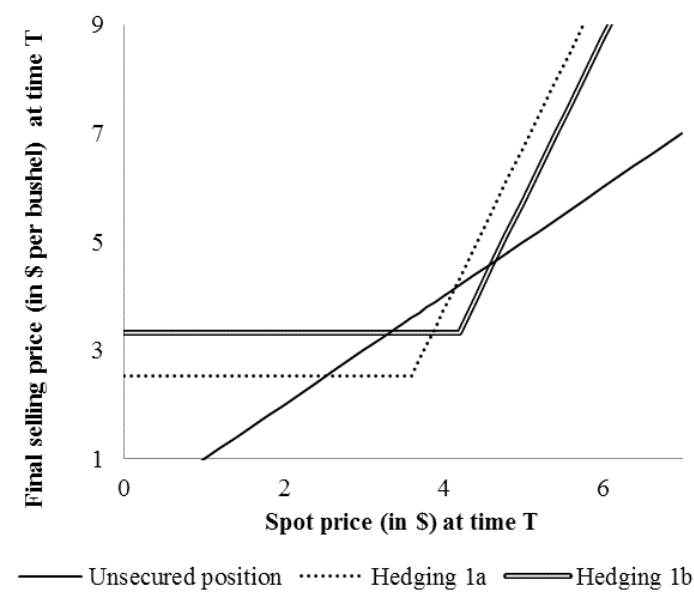

1: Strap strategy and its final corn selling price with various strike prices Source: Own design 
for hedging against price drop but also for hedging against the price increase.

In this case, the choosing of the put and call options depends on the location of the strike price, where the put strike should be set below the current underlying asset's price and the call strike above the current underlying asset's price. However, this strategy cannot be created without initial costs due to the paid amount of option premiums. Rusnáková and Šoltés (2012) proposed the LS strategy created by barrier options with the derived final selling price.

LS strategy anticipates a large move, upward or downward, of the underlying asset's price. If the underlying asset's price remains between the strike prices, we make our maximum loss. Therefore, the significant movement of the underlying asset in both directions is required to make a profit.

Tab. VII. shows the future market reward and final hedged selling price for the case of used LS strategy, where the floor hedged price position is in the amount of $X_{1}-p_{1 B}-c_{2 B}$, introduced the sum of analytical form of the relation (1), (2) and (4).

Assume the corn seller buys a December Corn futures put option contract at a strike price 3.6 USD/per bushel with the option premium 0.115 USD/per bushel and simultaneously buys call option contract at the strike price 4.0 USD/per bushel with the option premium 0.282 USD/per bushel. Based on formulas listed above, the final hedged selling prices with the presentation of the profit or loss from the hedging are calculated in Tab. VIII. The Fig. 2 illustrates the comparison of the results noted in the Tab. VIII and the unsecured position. If the cash market price is below 3.203 USD, the seller receives a minimum selling price 3.203 USD/per bushel, i.e. the strike price (3.6 USD) minus the premiums paid for the options (0.115 USD + 0.282 USD). In this case, the hedging variant is profitable. On the other hand, given hedging variant is also profitable in the strong increasing corn prices, i.e. above 4.397 USD when the growth of the profit is twofold compared to the unsecured position.

VII: Long Strangle strategy and its final selling price

\begin{tabular}{cccc}
\hline $\begin{array}{c}\text { Price scenarios of selected } \\
\text { commodity }\end{array}$ & Cash market price & Future market reward & Final hedged selling price \\
\hline $\mathrm{S}_{\mathrm{T}}<\mathrm{X}_{1}$ & $\mathrm{~S}_{\mathrm{T}}$ & $\mathrm{X}_{1}-\mathrm{S}_{\mathrm{T}}-\mathrm{p}_{1 \mathrm{~B}}-\mathrm{c}_{2 \mathrm{~B}}$ & $\mathrm{X}_{1}-\mathrm{p}_{1 \mathrm{~B}}-\mathrm{c}_{2 \mathrm{~B}}$ \\
$\mathrm{X}_{1} \leq \mathrm{S}_{\mathrm{T}}<\mathrm{X}_{2}$ & $\mathrm{~S}_{\mathrm{T}}$ & $-\mathrm{p}_{1 \mathrm{~B}}-\mathrm{c}_{2 \mathrm{~B}}$ & $\mathrm{~S}_{\mathrm{T}}-\mathrm{p}_{1 \mathrm{~B}}-\mathrm{c}_{2 \mathrm{~B}}$ \\
$\mathrm{~S}_{\mathrm{T}} \geq \mathrm{X}_{2}$ & $\mathrm{~S}_{\mathrm{T}}$ & $\mathrm{S}_{\mathrm{T}}-\mathrm{X}_{2}-\mathrm{p}_{1 \mathrm{~B}}-\mathrm{c}_{2 \mathrm{~B}}$ & $2 \mathrm{~S}_{\mathrm{T}}-\mathrm{X}_{2}-\mathrm{p}_{1 \mathrm{~B}}-\mathrm{c}_{2 \mathrm{~B}}$ \\
\hline
\end{tabular}

Source: Own design

VIII: Long Strangle strategy and its final selling price

\begin{tabular}{ccccc}
\hline \multirow{2}{*}{ Corn price scenarios } & \multirow{2}{*}{ Cash market price } & Final selling price & \multicolumn{2}{c}{ Profit/Loss of the hedging } \\
\cline { 3 - 4 } & & 3.203 & Min & Max \\
\hline $\mathrm{S}_{\mathrm{T}}<3.203$ & & 0 & 3.203 \\
$3.203 \leq \mathrm{S}_{\mathrm{T}}<3.6$ & $\mathrm{~S}_{\mathrm{T}}$ & $\mathrm{S}_{\mathrm{T}}-0.397$ & 0 & -0.397 \\
$3.6 \leq \mathrm{S}_{\mathrm{T}}<4.0$ & $2 \mathrm{~S}_{\mathrm{T}}-4.397$ & -0.397 & -0.397 \\
$4.0 \leq \mathrm{S}_{\mathrm{T}}<4.397$ & & $2 \mathrm{~S}_{\mathrm{T}}-4.397$ & 0 & -0.397 \\
$\mathrm{~S}_{\mathrm{T}} \geq 4.397$ & & 0 & $+\infty$ \\
\hline
\end{tabular}

Source: Own calculations

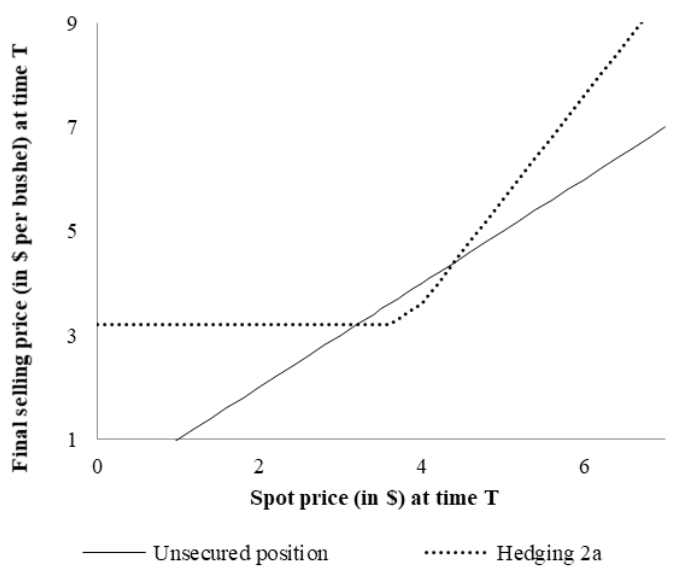

2: Long Strangle strategy and its final corn selling price Source: Own design 
The corn selling price is determined by using different combinations of the strike prices for put and call prices. Another possible combination is by buying a put option contract at a strike price $3.8 \mathrm{USD} /$ per bushel (the option premium 0.205 USD/per bushel) and by buying call option contract at the strike price 4.2 USD/per bushel (the option premium 0.213 USD/per bushel). Fig. 3 presents the comparison of the 2 hedged variants of this strategy. It's easy to see, the second variant (2b) is better for falling prices where the higher floor selling price is secured. But on the other hand, the first variant (2a) is better when the corn price increases.

Given LS strategy provides protection against falling corn price, but the strategy offers to sellers an opportunity to participate twice compared to the unsecured position during the price increase. There is a wide range of broad combinations to choose strike prices. However, the final decision depends on the seller.

\section{Short Put Ladder}

Previous option strategies cannot be created without initial costs. Therefore, the last introduced option strategy is more interesting due to a possible way to create it with no initial costs. The Short Put Ladder strategy (referred as SPL) is classified among vertical spreads, which are typically defined as two-legged option strategies with different strike prices but the same expiration date.

The SPL strategy is created by buying $n$ put options with a lower strike price $X_{1}$, the premium $p_{1 в}$ per option, simultaneously by buying $n$ put options with the middle strike price $X_{2}$ the premium $p_{2 s}$ per option and by selling $n$ put options with the highest strike price $X_{3}$ the premium $p_{3 B}$ per option, all with the same expiration date. The zero-cost is fulfilled if the condition $p_{3 S}>p_{1 B}+p_{2 B}$ is met. This strategy is a little bit harder for understanding, therefore it is only suitable for more advanced traders. In this case, the floor protection is secured in the amount of $X_{1}+X_{2}-X_{3}-p_{1 B}-p_{2 B}+p_{3 S}$, represents the sum of analytical form of the relation (1), (2) and (3). Derived final selling price for SPL strategy is in Tab. IX.

Assume the corn seller buys a December Corn futures put option contract at a strike price 3.6 USD/per bushel with the option premium 0.115 USD/per bushel, buys put option contract at the strike price $3.8 \mathrm{USD} /$ per bushel with the option premium $0.205 \mathrm{USD} / \mathrm{per}$ bushel and simultaneously sells put option contract at the strike price $4.2 \mathrm{USD} /$ per bushel with the option premium 0.440 USD/per bushel. The strategy is created without initial costs for option positions, where the farmer gains a profit

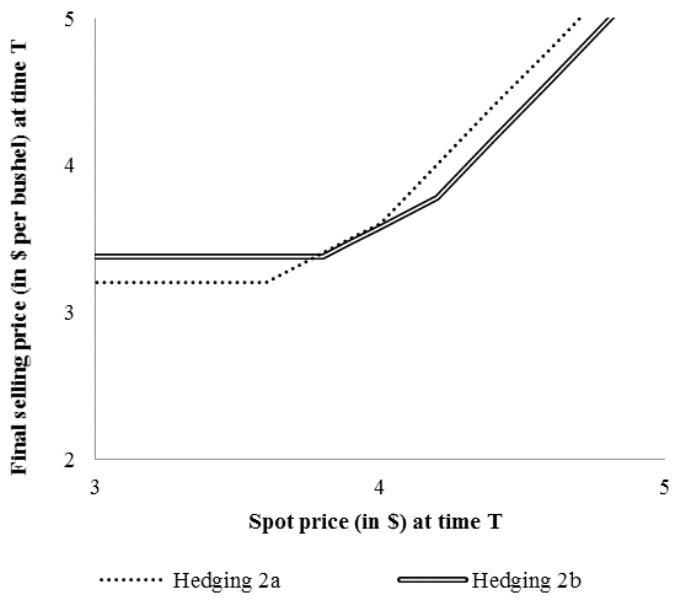

3: Long Strangle strategy and its final corn selling price with various strike prices Source: Own design

IX: Short Put Ladder strategy and its final selling price

\begin{tabular}{cccc}
\hline $\begin{array}{c}\text { Price scenarios of selected } \\
\text { commodity }\end{array}$ & Cash market price & Future market reward & Final hedged selling price \\
\hline $\mathrm{S}_{\mathrm{T}}<\mathrm{X}_{1}$ & $\mathrm{~S}_{\mathrm{T}}$ & $\mathrm{X}_{1}-\mathrm{S}_{\mathrm{T}}+\mathrm{X}_{2}-\mathrm{X}_{3}-\mathrm{p}_{1 \mathrm{~B}}-\mathrm{p}_{2 \mathrm{~B}}$ & $\mathrm{X}_{1}+\mathrm{X}_{2}-\mathrm{X}_{3}-\mathrm{p}_{1 \mathrm{~B}}-\mathrm{p}_{2 \mathrm{~B}}+\mathrm{p}_{3 \mathrm{~S}}$ \\
$\mathrm{X}_{1} \leq \mathrm{S}_{\mathrm{T}}<\mathrm{X}_{2}$ & $\mathrm{~S}_{\mathrm{T}}$ & $\mathrm{X}_{2}-\mathrm{X}_{3}-\mathrm{p}_{1 \mathrm{~B}}-\mathrm{p}_{2 \mathrm{~B}}+\mathrm{p}_{3 \mathrm{~S}}$ & $\mathrm{~S}_{\mathrm{T}}+\mathrm{X}_{2}-\mathrm{X}_{3}-\mathrm{p}_{1 \mathrm{~B}}-\mathrm{p}_{2 \mathrm{~B}}+\mathrm{p}_{3 \mathrm{~S}}$ \\
$\mathrm{X}_{2} \leq \mathrm{S}_{\mathrm{T}}<\mathrm{X}_{3}$ & $\mathrm{~S}_{\mathrm{T}}$ & $\mathrm{S}_{\mathrm{T}}-\mathrm{X}_{3}-\mathrm{p}_{1 \mathrm{~B}}-\mathrm{p}_{2 \mathrm{~B}}+\mathrm{p}_{3 \mathrm{~S}}$ & $2 \mathrm{~S}_{\mathrm{T}}-\mathrm{X}_{3}-\mathrm{p}_{1 \mathrm{~B}}-\mathrm{p}_{2 \mathrm{~B}}+\mathrm{p}_{3 \mathrm{~S}}$ \\
$\mathrm{~S}_{\mathrm{T}} \geq \mathrm{X}_{3}$ & $\mathrm{~S}_{\mathrm{T}}$ & $-\mathrm{p}_{1 \mathrm{~B}}-\mathrm{p}_{2 \mathrm{~B}}+\mathrm{p}_{3 \mathrm{~S}}$ & $\mathrm{~S}_{\mathrm{T}}-\mathrm{p}_{1 \mathrm{~B}}-\mathrm{p}_{2 \mathrm{~B}}+\mathrm{p}_{3 \mathrm{~S}}$ \\
\hline
\end{tabular}

Source: Own design 
in the amount of $0.12 \mathrm{USD} /$ per bushel. In this example, the final hedged selling prices for various price scenarios are calculated in Tab. $\mathrm{X}$. The floor hedged prices is in the minimum amount of $3.320 \mathrm{USD} /$ per bushel. From this level, the unsecured position is better only up to level 4.080 USD/per bushel, otherwise the SPL is better. The SPL strategy achieves a better result during the increase of prices but only for SPL strategies created without initial cost (in the amount of the profit from the option strategy). Fig. 4 illustrates the results noted in the Tab. X.
Next used combination of LS strategy is created as previous one, with the combination of the strike prices as 3.6, 4.0 and 4.4 USD/per bushel. Also, the combination of these strike prices is created without any initial cost (option strategy's profit is $0.164 \mathrm{USD} /$ per bushel), which causes the higher floor minimum selling price (3.364 USD/per bushel). Comparison of these two hedging variants is illustrated in Fig. 5. In case of falling corn price, the second strategy (3b) is better than the first strategy (3a) up to certain level when strategy 3 a crosses strategy $3 b$.

X: Short Put Ladder strategy and its final selling price

\begin{tabular}{|c|c|c|c|c|}
\hline \multirow{2}{*}{ Corn price scenarios } & \multirow{2}{*}{ Cash market price } & \multirow{2}{*}{$\begin{array}{c}\text { Final hedged selling } \\
\text { price }\end{array}$} & \multicolumn{2}{|c|}{ Profit/ Loss of the hedging } \\
\hline & & & Min & Max \\
\hline $\mathrm{S}_{\mathrm{T}}<3.320$ & & 3.320 & 0 & 3.320 \\
\hline $3.320 \leq \mathrm{S}_{\mathrm{T}}<3.6$ & & 3.320 & 0 & -0.280 \\
\hline $3.6 \leq \mathrm{S}_{\mathrm{T}}<3.8$ & & $\mathrm{~S}_{\mathrm{T}}-0.280$ & -0.280 & -0.280 \\
\hline $3.8 \leq \mathrm{S}_{\mathrm{T}}<4.080$ & $\mathrm{~S}_{\mathrm{T}}$ & $2 S_{T}-4.080$ & 0 & -0.280 \\
\hline $4.080 \leq \mathrm{S}_{\mathrm{T}}<4.2$ & & $2 \mathrm{~S}_{\mathrm{T}}-4.080$ & 0 & 0.012 \\
\hline $\mathrm{S}_{\mathrm{T}} \geq 4.2$ & & $\mathrm{~S}_{\mathrm{T}}+0.12$ & 0.12 & $+\infty$ \\
\hline
\end{tabular}

Source: Own calculations

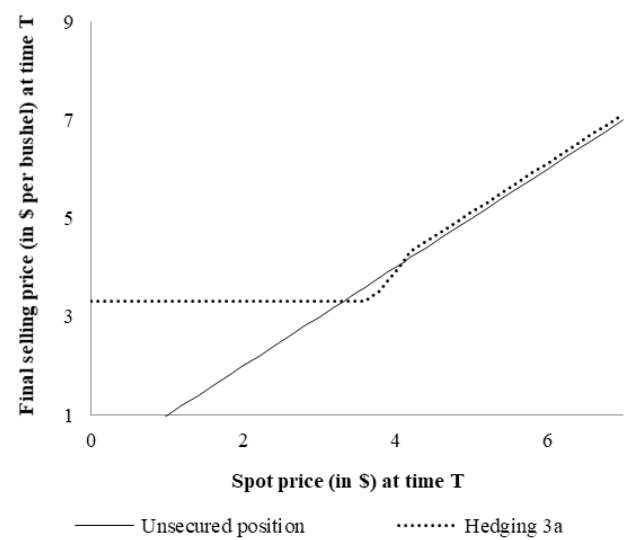

4: Short Put Ladder strategy and its final corn selling price Source: Own design

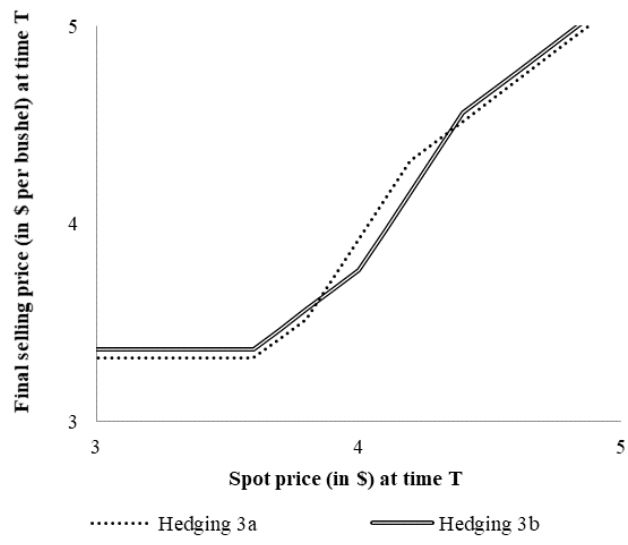

5: Short Put Ladder strategy and its final corn selling price with various strike prices Source: Own design 


\section{DISCUSSION}

Corn sellers do not have the perfect hedging strategy which will suit all market conditions. At first, they should learn something more how to evaluate and compare given strategies. Also, there has not been included any transaction or any other charges and a basis is 0 USD to keep things simple. Analysed hedging variants are similar to each other and belong to the group of high volatility strategies. The point is, that the hedger does not care which direction corn futures moves, as long as it moves explosively in one direction or the other with the demonstration of how to take advantage of it.

Based on the merge of Tab. VI, VIII and X to Tab. XI, we compare the corn's final selling prices of studied hedging variants A with the cash market prices of the unsecured position. There is calculated

XI: Comparison of the $\mathrm{P} / \mathrm{L}$ created hedging variants

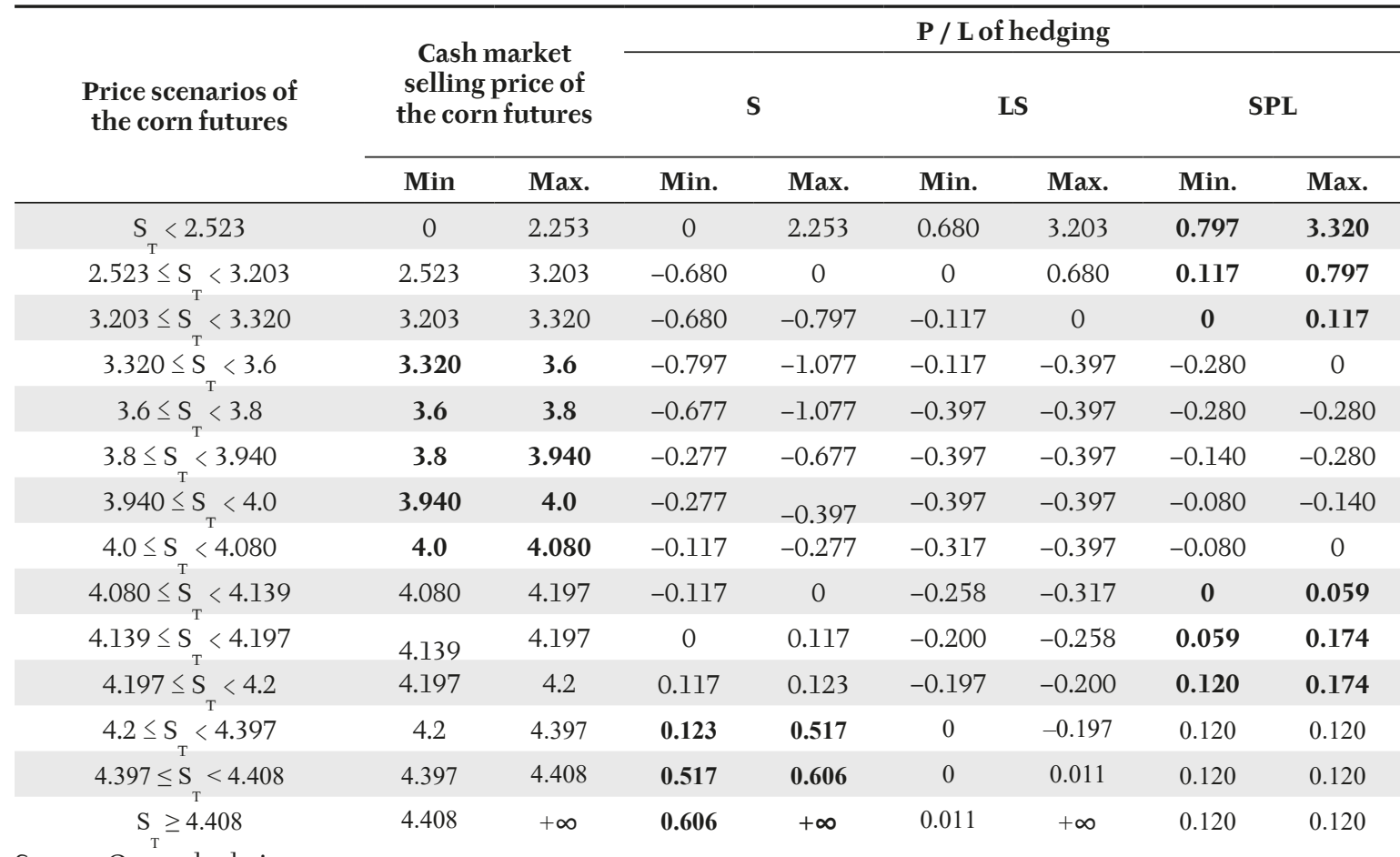

Source: Own calculations

Notes: S (Strap), LS (Long Strangle), SPL (Short Put Ladder), P (Profit), L (Loss)

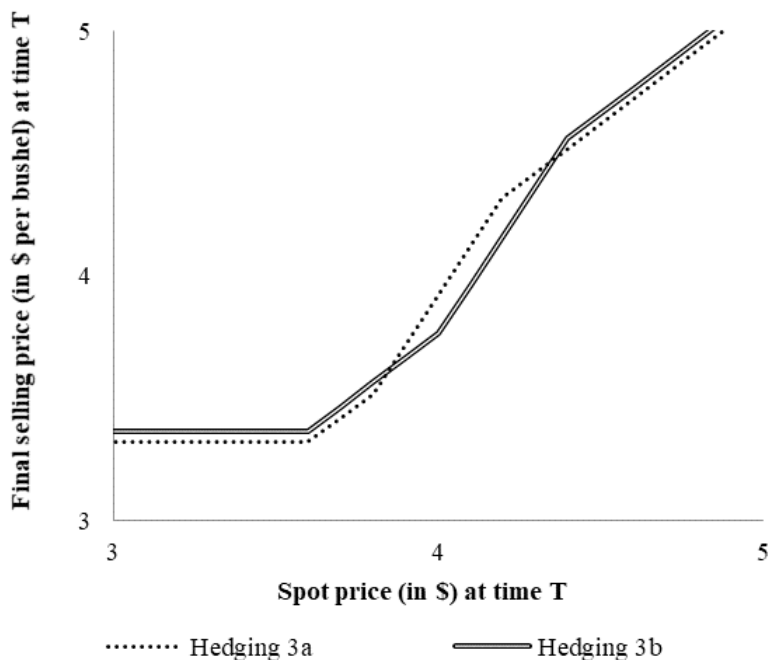

6: Comparison of corn price risk management strategies with the unsecured position Source: Own design

Notes: 1A (Strap), 2A (Long Strangle), 3A (Short Put Ladder) 
a minimum (min) and maximum (max) profit or loss of hedged variants, which is the difference between a secured position and a cash market selling price. It is valid, that if this difference is positive, it is profit (more than 0), the hedged variant is better than the unsecured position. Otherwise, the unsecured position is better if the difference is negative (less than 0 ).

To better identify results from Tab. XI, following Fig. 6 compares the corn futures hedged selling strategies and graphical illustration of numerical results of the corn's final selling prices under various expected future cash market prices. From this point, each strategy has its own advantages and disadvantages. Based on results from Tab. XI illustrated in Fig. 6, we can conclude that:

- SPL strategy ensures the highest corn selling price if the corn future cash market price is lower than 3.320 USD/ per bushel, but it enables to participate in corn price increase. Only this strategy is possible to create without initial costs of given option strategy.

- The unsecured position offers better corn selling price as others hedging variants if the corn future price is in the range of $\langle 3.320 ; 4.080\rangle$.

- SPL strategy establishes the higher corn selling price only for the corn future cash market price in the range of $\langle 4.080 ; 4.197\rangle$, but it enables to participate in the corn price increase with the limited profit (0.120 USD/per bushel) in comparison to the unsecured position.

- S strategy ensures the best corn selling price only in case of the corn future cash market price increase, i.e. it is higher than 4.197 USD/per bushel. Using this strategy allows to participate disproportionally twice higher than the unsecured position.

- LS strategy establishes the floor corn selling price in the middle.

By comparing introduced hedging variants, the following theoretical conclusions can be deduced which widen existing results. So, in summary, by SPL strategy, the corn producer establishes the highest floor selling price compared to others variants. If the corn future cash market price increases, then the strategy participates proportionally with the unsecured position with the limited profit in the amount of positive difference of received and paid option premiums. On the other hand, S strategy is the most expensive compared to others analysed but ensures the producer disproportionally two times higher selling price in case of the corn future cash market price increase. In the case of LS, it is created with lower costs than S strategy and establishes the floor corn selling price in the middle of analysed strategies. Eventually, all presented strategies provide the minimum price level but also allow the producer to participate in the corn price increase what will be their advantage. These strategies are only chosen for the presentation of the possible ways in corn price risk management. Besides that, there exists a lot of other hedged strategies using options available for sellers that hedge against the price drop and simultaneously speculate on a price increase.

Based on our approach, the final Tab. XII summarizes important facts about analysed hedging variants, which the hedgers should remember in future decisions. From the analysed hedging way only the SPL strategy can be created without initial costs with the right combination of the put strike prices. Therefore, the consensus is that buying options can be very expensive. One way of dealing with this concern is to sell options. In this case, using short options in conjunction with long options can generate the desired protection with a more attractive cash outlay requirement.

These three basic strategies can be used to help protect producers from excessive losses. Each strategy carries pros and cons like timing risk, degree of downside coverage, capital outlay and the probability of success. As seen in the above example, hedging does not guarantee that the profit or loss in the futures market will fully offset the loss or profit in the cash market.

Finally, the selection of the right options is complicated by the fact that a whole variety of strike prices is available, ranging from very cheap options (out of the money options) to very expensive (in the money) ones. Therefore the hedger should choose the strategy depending on the number of options purchased and sold simultaneously. Also, there can be one question. Which is the right one to buy? But, no single answer is right for all. Therefore, the next approach might help in the selection process.

XII: Important facts about corn option hedging strategies

\begin{tabular}{lccccc}
\hline \multicolumn{1}{c}{ Hedging variant } & $\begin{array}{c}\text { Floor price } \\
\text { level }\end{array}$ & $\begin{array}{c}\text { Ceiling price } \\
\text { level }\end{array}$ & $\begin{array}{c}\text { Profit of } \\
\text { hedging }\end{array}$ & $\begin{array}{c}\text { Loss of } \\
\text { hedging }\end{array}$ & Zero-cost \\
\hline Strap & limited & unlimited & unlimited & limited & no \\
Long Strangle & limited & unlimited & unlimited & limited & no \\
Short Put Ladder & limited & unlimited & limited & limited & yes \\
\hline
\end{tabular}

Source: Own design 


\section{CONCLUSION}

Every agricultural seller tries to make cash sales at the best possible price. It is easier to say than done because the future cannot be predicted. Therefore, commodity sellers use mainly the options market to establish price floors and potentially participate in the price increase of agricultural product. Hedging with options is often considered as an advanced investing strategy. In the real world, there are not many commodity producers who use options. However, for those who understand the mechanism and who carefully study the possibilities, they provide an extraordinarily flexible tool of risk management. Different existing combinations of call and put options offer many strategies for those that want to hedge the risk of their portfolios and take advantage of it. Therefore, a general literature overview of the risk management tools using derivatives was presented in the introduction. The paper introduced three option strategies (Strap, Long Strangle and Short Put Ladder strategy) in the corn risk management, how they are created and how hedgers profit from their designs. The purpose was to analyse and compare given option hedging strategies. Our results can be used in praxis, where commodity sellers decide which hedging variant is the more suitable. The approach was applied in hedging of corn, where was demonstrated the usage of hedging against falling price in selected model variants. Also, details of these strategies above have been provided.

Our finding show that all hedging variants establish the floor corn selling price, but only the Short Put Ladder strategy secures the highest floor price compared to others variants. Also, ceiling price level is not limited for all hedging variants, what it is a big advantage. In the case of Short Put Ladder strategy, hedger can participate proportionally to the unsecured position reduced by purchase and sale of a number of options. However, Strap strategy is the most expensive one, compared to other variants, but it is compensated with the disproportionally higher corn selling price in case of the corn future cash market price increase. Similarly, Long Strangle strategy provides disproportionally higher corn selling price in case of increasing corn market price, but this price is lower than to Strap strategy. On the other hand, only Short Put Ladder strategy can be created without initial costs.

The paper has illustrated different ways of agricultural option hedging strategies creation against falling prices, which guarantees to a seller a minimum selling price. Suitability of options depends on the hedgers's ability to match an appropriate strategy with a particular objective at a given time. Also, the selection of the strike prices is flexible and depends on the farmers' decisions concerning their market risk exposure.

\section{REFERENCES}

AMAITIEK, O. F. S., BÁLINT, T. and REŠOVSKÝ, M. 2010. The Short Call Ladder strategy and its application in trading and hedging. Acta Montanistica Slovaca, 15(3): 171-182.

ARMEANU, D., ISTUDOR, N. and DINICA, M. C. 2013. The optimal hedging ratio for agricultural market. Economic computation and economic cybernetics studies and research, 47(3): 37-52.

BOBRIKOVÁ, M. 2016. Weather Risk Management in Agriculture. Acta Universitatis Agriculturae et Silviculturae Mendelianae Brunensis, 64(4): 1303-1309.

CME. 2006. CME Commodity Trading Manual. CME Group. Chicago: CME Publishing.

CME GROUP. 2017. Corn Futures Quotes. CME Group. [Online]. Available at: http://www.cmegroup.com/ trading/agricultural/grain-and-oilseed/corn.html [Accessed: 2017, August 29].

COHEN, G. 2005. The Bible of Options Strategies. New Jersey: Pearson Education.

GARCIA, P. and LEUTHOLD, R. M. 2004. A selected review of agricultural commodity futures and options markets. European review of agricultural economics, 31(3): 235-272.

GEMAN, H. 2005. Commodities and Commodity Derivatives Modeling and Pricing for Agriculturals, Metals and Energy. Chichester: John Wiley \& Sons Ltd.

GEMAN, H. 2008. Risk Management in Commodity Markets: From Shipping to Agriculturals and Energy. Chichester: John Wiley \& Sons Ltd.

HULL, J. C. 2012. Options, Futures and Other Derivatives. New Jersey: Prentice-Hall.

KOLB, R. W. 1995. Understanding options. John Wiley \& Sons, Ltd., Hardcover.

KOLB, R. W. and OVERDAHL, J. A. 2010. Financial Derivatives: Pricing and Risk Management. New Jersey: JohnWiley \& Sons, Inc.

LARSON, D. F., VARANGIS, P. and YABUKI, N. 1998. Commodity Risk Management and Development. Policy Research Working Paper no. WPS 1963. Washington DC: World Bank.

LEONI, P., VANDAELE, N. and VANMAELE, M. 2014. Hedging strategies for energy derivatives. Quantitative Finance, 14(10): 1725-1737.

RATA, D. A. and CINADE, L. O. 2009. Hedging: An important tool in agriculture risk management. Agricultural Management, Lucrari Stiintifice Seria I, Management, 11(2): 1-6.

RUSNÁKOVÁ, M. and ŠOLTÉS, V. 2012. Long strangle strategy using barrier options and its application in hedging. Actual Problems of Economics, 134(8): 452-465. 
RUSNÁKOVÁ, M. 2015. Commodity price risk management using option strategies. Agricultural Economics - Zemedelska Ekonomika, 61(4): 149-157.

RUSNÁKOVÁ, M., ŠOLTÉS, V. and SZABO, Z. K. 2015. Short combo strategy using barrier options and its application in hedging. Procedia Economics and Finance: EMQFB, 32: 166-179.

SHANNON, H. D. and MOTHA, R. P. 2015. Managing weather and climate risks to agriculture in North America, Central America and the Caribbean. Weather and Climate Extremes, 10(Part A): 50-56.

SIVAKUMAR, M. V. K. and MOTHA, R. P. 2007. Managing Weather and Climate Risks in Agriculture. Berlin: Springer-Verlag.

STULZ, R. 2002. Risk Management and Derivatives. South-Western College Publishing.

ŠOLTÉS, M. and HARČARIKOVÁ, M. 2015. Analysis of Nova 1 strategy formed by barrier options and its application in hedging against a price drop in oil market. Acta Montanistica Slovaca, 20(4): 311-318.

ŠOLTÉS, V. 2002. Financial Derivatives [in Slovak: Finančnéderiváty]. Košice: EkF TUKE.

ŠOLTÉS, V. and AMAITIEK, O. F. S. 2010. The short put ladder strategy and its application in trading and hedging. Theory Methodology Practice, 6(2): 77-84.

ŠOLTÉS, V. and RUSNÁKOVÁ, M. 2013. Hedging Against a Price Drop Using the Inverse Vertical Ratio Put Spread Strategy Formed by Barrier Options. Inzinerine Ekonomika - Engineering Economics, 24(1): 18-27.

TALEB, N. N. 1997. Dynamic Hedging: Managing Vanilla and Exotic Options. Wiley \& Sons.

TAUŠER, J. and ČAJKA, R. 2014a. Hedging techniques in commodity risk management. Agricultural Economics - Zemedelska Ekonomika, 60(4): 174-182.

TAUŠER, J. and ČAJKA, R. 2014b. Weather derivatives and hedging the weather risks. Agricultural Economics - Zemedelska Ekonomika, 60(7): 309-313.

TOMEK, W. G. and PETERSON, H. H. 2001. Risk Management in Agricultural Markets: A Review. Journal of futures markets, 21(10): 953-985.

ZMEŠKAL, Z. 2004. Hedging strategies and financial risks. Finance a úvèr - Czech Journal of Economics and Finance, 54(1-2): 50-63. 